\title{
O CONCERTO DE ISPINHO E FULÔ E A PEDAGOGIA FREIREANA
}

A Cia. do Tijolo surge em São Paulo, quando em 2007 alguns artistas de diferentes formações iniciam uma pesquisa sobre a vida e a obra do poeta cearense Patativa do Assaré, além da teoria do educador pernambucano Paulo Freire. O grupo não pretendia dramatizar um espetáculo biográfico, logo a teoria freireana foi utilizado como instrumento metodológico, social e politico: “Aprender a ler a vida para depois ler as palavras. Patativa era a própria encarnação dessa máxima de Paulo Freire. Um homem que frequentou a escola por seis meses, mas, mesmo assim, aprendeu a ler "nos livros da natureza”, como ele mesmo dizia” (MERCADANTE, 2015).

As principais referências da obra do educador Paulo Freire, estudada pelo grupo foram os seguintes títulos: A pedagogia do oprimido e A pedagogia da autonomia. Baseado então nessas obras surge o nome da companhia, que propõe uma homenagem ao Freire, num de seus estudos:

\footnotetext{
O primeiro passo no processo de alfabetização do método criado por Paulo Freire é o levantamento do universo vocabular dos grupos com que se trabalha; são palavras ligadas às experiências existenciais, profissionais e políticas dos participantes dos diferentes grupos. Foi assim que em Brasília, cidade ainda em construção nos anos 60, surgiu entre os estudantes de Paulo Freire a palavra TIJOLO. (MERCADANTE, 2009).
}

Com suporte teórico dos estudos de Paulo Freire, e com literatura e a vida de Patativa do Assaré como mote para criação dramatúrgica, a companhia estreia em agosto de 2009 o espetáculo: Concerto de Ispinho de Fulô. Com a proposta de retratar a vida e obra do poeta, porém sem ater-se apenas a biografia dele, mas procurando retratar a temática de suas poesias e ainda procurando um contexto político dentro de um fato histórico do qual Patativa foi testemunha, o massacre do Sitio Caldeirão da Santa Cruz do Deserto. Parecia uma grande revista teatral de fatos do nordeste do século XX, produzido por um grupo de São Paulo-SP que, dentro do espetáculo, assumiam-se enquanto grupo não nordestino e mostravam ao público presente suas deficiências para tratar de assuntos até então desconhecidos por eles como, por exemplo, a seca.

O grande diferencial desse espetáculo é que ele tem na figura de Patativa do Assaré um mote central para buscar outros temas que englobem a dramaturgia do espetáculo, mesclando outras literaturas e músicas; assimilando a vida do poeta com a dos próprios 
atores, numa construção totalmente coletiva. Saindo do modo clássico de construção dramatúrgica centrado num texto dramático escrito por um dramaturgo.

O espetáculo destacou-se e ganhou elogios por fugir do óbvio biográfico e ilustrativo, em detrimento de uma busca por retratar o universo nordestino, num tom político acentuado; ao mesmo tempo em que apresenta o poeta cearense, sua obra, sua vida, seu contexto e suas lutas.

O Concerto de Ispinho e Fulô é uma obra aberta às mais variadas análise, afinal, está se falando de um processo coletivo estabelecido pelo grupo que pesquisou e buscou as mais variadas referências. Com o objetivo de contar o legado de um poeta nordestino semianalfabeto do século passado, que muitos esquecem ou desconhecem, mas que por mais antiga que seja a sua obra, ela se mantém atualizada: infelizmente as problematizações de outrora são semelhantes às da atualidade. Logo, o espetáculo tem seu diferencial no constante questionamento de como seu trabalho pode implicar mudanças numa sociedade brasileira. Esse ímpeto de transformar a sociedade, essa busca incessante de mudar aquilo que não está correto, remete a uma frase dita por Paulo Freire, a grande influência do grupo: “mudar é difícil, mas é possível”.

\section{REFERÊNCIAS}

CIA DO TIJOLO. Cia do Tijolo. Disponível em:

<http://concertodeispinhoefulo.blogspot.com.br/> Acesso em: 15 nov. 2016, 10:34

pesquisa pela Cia. Do tijolo.

Concerto de Ispinho e Fulô. 2009. Roteiro do espetáculo cedido à

FREIRE, Paulo. Pedagogia da autonomia: Saberes necessários à prática educativa. Rio de Janeiro: Paz e Terra. 2013

. Pedagogia do oprimido. Rio de Janeiro: Paz e Terra. 2006.

MERCADANTE, Rodrigo. Patativa, Paulo Freite e a Cia. Do Tijolo. 2009. Disponível em: <http://concertodeispinhoefulo.blogspot.com.br/search/label/Sobre\%20n \%C3\%B3s> Acesso em: 15 nov. 2016, 14:32.

. Rodrigo Mercadante e o teatro libertador da Cia. do Tijolo. 2015. Disponível em: < http://www.topvitrine.com.br/detalhes/rodrigo-mercadante-e-oteatro-libertador-da-cia-do-tijolo> Acesso em: 14 ago. 2017, 10:00. 